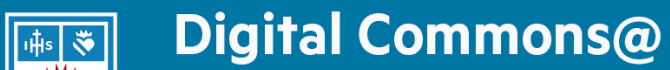

Loyola Marymount University

LMU Loyola Law School

\section{Journal of Catholic Education}

March 2017

\section{The Case for a Socio-Cultural Approach to Literacy and Student Support Services}

\author{
Marina Palomino-Bach \\ Saint Martin de Porres High School \\ Julia Fisher \\ St. Martin de Porres High School
}

Follow this and additional works at: https://digitalcommons.Imu.edu/ce

Part of the Curriculum and Instruction Commons, Curriculum and Social Inquiry Commons, and the Other Education Commons

\section{Recommended Citation}

Palomino-Bach, M., \& Fisher, J. (2017). The Case for a Socio-Cultural Approach to Literacy and Student Support Services. Journal of Catholic Education, 20 (2). http://dx.doi.org/10.15365/joce.2002102017

This Education in Practice Article is brought to you for free with open access by the School of Education at Digital Commons at Loyola Marymount University and Loyola Law School. It has been accepted for publication in Journal of Catholic Education by the journal's editorial board and has been published on the web by an authorized administrator of Digital Commons at Loyola Marymount University and Loyola Law School. For more information about Digital Commons, please contact digitalcommons@lmu.edu. To contact the editorial board of Journal of Catholic Education, please email JCE@nd.edu. 


\title{
The Case for a Socio-Cultural Approach to Literacy and Student Support Services
}

\author{
Marina Palomino-Bach and Julia Fisher \\ St. Martin de Porres High School, Cleveland, Ohio
}

Many urban Catholic high schools pride themselves as developing our students in a holistic way. In these schools, educators are able to develop and support their students in both a moral and an academic sense. This belief in educating the whole child is appealing to many families, especially those in our most underserved urban contexts. Families in these urban contexts look toward Catholic high schools as offering the necessary holistic support and guidance needed to achieve academic, collegiate, and moral success and stability. As co-developers of a newly launched Academic Resource Center within one urban Catholic high school setting, however, we recognize that while our education may appear holistic in nature and philosophy, oftentimes our understandings of student ability and literacy behaviors may be radically underdeveloped.

Keywords: literacy, high school, support services, urban education

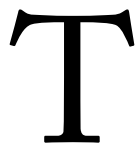

his article describes an Academic Resource Center located within an urban Catholic high school. The Center, designed to serve "at risk" students, offers regular tutoring and academic support-including literacy support--that is sensitive to socio-cultural variances in literacy styles and traditions. Many of the students served by the Center have been labeled as "deficient" and "at risk" through their performance on norm-referenced assessments-standardized tests which are currently in use in student support services throughout the US. As educators, we recognize that the "norms" these exams reference are based on a white, middle-class, Eurocentric literary tradition. In response, we raise the following questions:

- In what ways are students of color, immigrant students, or students from lower-socioeconomic households being unjustly labeled and scrutinized as a result of their varying literacy styles?

- How might we vary our schools' curriculum and student support services so that teachers and school staff can more fully understand and support students who fall outside of the Eurocentric, white, middle class discourse of power?

Journal of Catholic Education, Vol. 20, No. 2, March 20I7, 208-214. This article is licensed under a Creative Commons Attribution 3.0 International License. doi: Io.15365/joce.20021020I7 


\section{Underlying Assumptions}

As practitioners working to teach through a socio-cultural understanding of literacy, our first concern is to question the concept of literacy as a whole. What does it mean to be a literate individual? What does it mean to read? What does it mean to write? What texts must one be able to read and write to be considered literate? And who is determining the answers to the questions listed above? Whose voices and literacy practices are we hearing and who are we not?

In considering these queries, we turn to literacy theorist James Paul Gee (1992) to establish a socio-cultural approach to understanding the questions above. Gee (1992) explains literacy as a "socially accepted....(way) of using language, of thinking, and of acting that can be used to identify oneself as a member of a socially meaningful group or...network" (p. 2I). Gee continues to explain the many socially accepted ways of communicating at play within people's personal identities and social affiliations. For example, the modes of communication, terminology, and jargon used by doctors in a hospital setting is different from the ways teachers communicate with their students and colleagues. A public defender communicates ideas in a courtroom in ways that are very different than those used by a salesperson, a corporate CEO, a carpenter, or a factory assembly-line worker. Language, thought, and action are not only linked, but context-dependent and fluid. The communication demands of one's lived experiences shift depending upon the socio-cultural context at hand. As educators, we question whether the literacy expectations in schools should similarly be understood as context-dependent and fluid.

As an English teacher and reading specialist in urban private and Catholic schooling, Marina Bach-Palomino has administered many assessments to students. These assessments require students to decode and comprehend a variety of fiction and nonfiction texts. They have been asked to pronounce words such as "berths," "chauffeur," "rendezvous," and "irrigated." They have been required to comprehend passages about ski vacations, agricultural practices, and cruise ships-experiences that are often completely outside of the experiences of students in our school. When considering these norm-referenced, standardized assessments (assessments which are used primarily to determine intellectual ability and capacity) it becomes clear that these texts offer a fixed rather than fluid understanding of literacy. In other words, they are assessing one socially acceptable way of communicating, which, we believe is reflective of the literacy tradition of the white, middle/upper-middle class discourse of power. 
Students who live in large, urban communities often bring with them a different set of background knowledge and a different socially accepted form of communicating than is required of them by these standardized exams. When these exams are being used to judge the students' mental capacities, those students whose identity and experiences do not align with the dominant discourse are labeled as deficient.

\section{Program Context}

The Academic Resource Center uses a socio-cultural approach to literacy to support students within one urban, Catholic high school in a large midwestern city. The school is located roughly three miles east of the city's bustling downtown hub and is surrounded by both low-income housing as well as newly established independent businesses in the neighborhood's gentrified locals.

The school serves primarily African American students (85\% of the student population) while also serving a smaller portion of Hispanic (Io\%) and Caucasian (5\%) students. Students represent all regions of the city and many of the immediate surrounding suburbs. The majority of students use public transportation (bussing) to travel to school, some journeys taking well over an hour to complete. In addition, 100\% of students enrolled in the school qualify for free or reduced lunch and all families receive government assistance in the forms of vouchers and school assistance in the form of work/ study programs to help pay their yearly tuition.

The school's Academic Resource Center was planned during the 20I42015 academic year and formally launched in August 2015, at which time Bach-Palomino was hired as the center's co-developer and Reading Specialist. The purpose of the Center is to support students in order to combat issues of student retention and academic failure. For the 20I3-20I4 academic year, the school had, on average, a $79 \%$ annual retention rate across the four grades. The school had a $58 \%$ cohort retention for the class of 2014 , meaning that only $58 \%$ of the students who began as $9^{\text {th }}$ graders in August 2010 graduated from the school as seniors in June 20I4. Yearly student turnover occurred as a result of many academic and behavioral factors; however, results from informal polling and conversations with former students and families showed that oftentimes students' decisions to transfer resulted from their feeling unsupported in completing their academic requirements. 
In order to offer greater academic support to students, Julia Blanchard collaborated with the school's principal to begin planning for the Academic Resource Center during the 20I4-20I5 academic year after hearing of a similar program in another urban, Catholic high school. During that time, the two initial collaborators laid out the Center's mission and underlying beliefs, a portion of which is as follows:

When we accept a student..., we commit to supporting that student through graduation. Students enter St. Martin de Porres at various academic levels, with unique strengths and deficits, and we accept the whole student, believing in his or her ability to succeed and excel here. For students who struggle to meet the academic standards required of them at St. Martin de Porres the Academic Resource Center offers students personalized support in their areas of need.

The bolded portion of the mission statement above demonstrates an important underlying assumption of the Academic Resource Center's philosophy - the belief that all students, regardless of test scores or academic labels, have the capacity to succeed and excel. This statement also demonstrates our view that the data gathered from norm-referenced assessments is both limited in the perspective it offers of student potential and even more so limiting in its presentation of the extraordinary talents the students offer to the class environment. In other words, in establishing the Academic Resource Center, the planning team recognized the ways in which test scores were both unreliable and limited in their understanding of student potential.

\section{Creating The Academic Resource Center}

During final planning of the Academic Resource Center in August of 2015, we had a common desire to establish a space in which students felt respected, supported, and cared for as both intellectuals and individuals. In order to do this, the Center's co-developers established and agreed upon program verbiage and format prior to the program's launch. These shifts were orchestrated in order to create a differentiation in environment between the school's classrooms and the Academic Resource Center's program. We hoped that the feel of the Center's environment would lead to more student buy-in of the program. The agreed-upon verbiage and format are as follows:

I. Students attend the Academic Resource Center daily during their previously scheduled study hall class period. Students are invited to attend the optional after-school program as desired and needed. 
2. Students are registered in the program for at least one quarter of the academic year, but can stay for the duration of the school year if the need and desire existed.

3. Students are enrolled in the daily program primarily through a process of teacher, faculty and family recommendations.

4. The Academic Resource Center is staffed by one Reading Specialist, one school volunteer, and six classroom teachers, who attend one class period throughout the day in replacement of their study hall duties.

5. Each Academic Resource Center class period is staffed by at least two to four staff members, leading to an average student-to-teacher ratio of 4:I during each class session.

6. All center support staff assume the role of mentors rather than teachers. By assuming the role of mentor, program support staff focus on developing strong mentor/student rapport in addition to offering academic support.

7. All students assume the role of Academic Resource Center crew. By taking this role, students actively acknowledged the ways in which they have the capacity, ability, and responsibility to support one another in their academic endeavors, similarly to the ways in which a crew of any vessel plays an active and vital role on that vessel as well.

\section{Program Outcomes}

In the first five months of operation, the Academic Resource Center has grown thriving mentor/crew relationships. In addition, crew members' academic outcomes as well as their own understandings of their academic abilities have noticeably risen.

Mentors support their crew through regular tutoring and relationship building while also serving as a much-needed liaison between student and teachers as well as between the school and home. Mentors communicate with students' families on a bi-weekly basis, discussing student success strategies, upcoming assignments and exams and also arranging after-school tutoring opportunities with individual classroom teachers as needed. Mentors also serve as student advocates by raising concerns with grades and academic content to teachers, teacher coaches, and administrators on an as-needed basis.

Tenth graders enrolled in the Academic Resource Center have demonstrated a quarterly grade point average growth after being participants in the program. The students' average GPA increased 0.75 points from quarter one of the 2014-2015 school year (a I.70 average GPA) to quarter one of the 20152016 school year (a 2.45 average GPA). 
Ninth grade participants also demonstrate a higher average quarterly GPA than their $10^{\text {th }}$ grade counterparts. A difference of 0.4 grade points can be seen when comparing the $9^{\text {th }}$ grade crew members to their ${ }^{\text {th }}{ }^{\text {th }}$ grade counterparts' performance during the first quarter (QI) of their $9^{\text {th }}$ grade year. Ninth grade participants in the Academic Resource Center earned an average GPA of 2.26 during QI of the 2015-2016 year, while $10^{\text {th }}$ grade participants earned an average GPA of I.8I during QI of their 20I4-20I5 $9^{\text {th }}$ grade year.

Student anecdotal evidence also shows students self-identifying more often as capable and intellectual individuals and scholars. For many of the students, this an identity that is in direct contrast to the labels they had been given previously through assorted standardized assessments and academic records. One student participant, Maria reflected on her growth in the Academic Resource Center program by writing the following: "I'm...starting to improve on speaking in front of people and turning in late work and keeping my grades up." In a separate reflection, Maria explained that working on a History project in the Center helped her feel confident and comfortable presenting in front of others.

Another $10^{\text {th }}$ grade student, Roan, showed a $0.76 \mathrm{GPA}$ growth from QI of her $9^{\text {th }}$ grade year to QI of her $10^{\text {th }}$ grade year, increasing her GPA from 2.22 to 2.77 quarterly GPA . Roan regularly tutors three other students enrolled in the program.

Two additional ro $^{\text {th }}$ grade students, Da'Juana and Malaya, attend the Academic Resource Center's after-school program daily in addition to their regularly scheduled class. Prior to their midterm exams, Da'Juana and Malaya took their regular 75 minute bus ride to school meet their mentor on a Saturday afternoon for 3 -hour study session to review exam study guides one last time. On this Saturday, Da'Juana's mentor noted her saying, "Ya'll never getting me out of the ARC. (Academic Resource Center). I'm [sic] feel smart here."

\section{Reflections}

Whereas the outcomes of the first five months of program operations appear optimistic and beneficial to students, the question remains as to whether or not the Center's work and mission are actively pushing back against assumptions about academic and intellectual deficits among our nonwhite, non-middle class students. Is our work within the Academic Resource Center helping to expand our school's understanding of literacy and student potential, or are we acting as an academic broker as our students work to navigate the demands of the discourse of power? Are we striving to reverse the 
negative labels assigned to our crew via unreliable assessments? Are program operations being sensitive to a socio-cultural approach to literacy or do we remain stuck within the confines assigned to us by the discourse of power?

We would argue that the answers to the questions above are two-fold and that any answer requires both a philosophical and practical shift in an individual's teaching practice. Whereas the mentors in the Academic Resource Center recognize the socio-cultural bias of norm-referenced exams and standardized assessments, and whereas the mentors also recognize the limited perspective they offer regarding student ability, there needs to be a larger dialogue around these issues with the school's teaching community at large. In other words, the dialogue regarding the questions above cannot be limited to the Academic Resource Center personnel, but need to include the entire school's teaching staff as well.

In order to more fully encapsulate a socio-cultural approach to literacy, we as a united teaching staff must shift not only our understanding of student ability but also our school's curricular choices. We must work to ensure that student learning experiences are centered in their real worlds and relevant to their lived experiences. We must provide texts that are engaging, accessible, and relatable. We must frame our mathematic and scientific real-world scenarios and examples around the realities of our students rather than the realities of the discourse of power.

Until we frame our curricular choices around the students we serve rather than the societal expectations of what is to be taught, we perpetuate labeling students who do not achieve on traditional academic assessments as deficient. In other words, until we critically review and alter the content that is delivered, the Academic Resource Center's mentors and other teachers working in similar capacity continue to play the role of academic broker, rather than student advocate.

\section{References}

Gee, J. P. (1992). What is literacy? In P. Shannon (Ed.), Becoming political: Readings and writings in the politics of literacy education (pp. 2I-28). Portsmouth, NH: Heinemann.

Marina Palomino-Bach is an English teacher and reading specialist in Cleveland, Ohio. She research is primarily on issues of critical literacy, the use of YA texts, and teacher research.

Julia Fisher lives in Cleveland, Obio and is a Theater teacher and Academic Resource Center co-director. 